Mesoporous LaMnO3+delta perovskite from spray - pyrolysis with superior performance for oxygen reduction reaction and $\mathrm{Zn}$ - air battery

Kuai, Long

2018-01

Kuai , L, Kan , E , Cao , W , Huttula , M , Ollikkala, S, Ahopelto , T, Honkanen , A-P , Huotari , S , Wang , W \& Geng , B 2018 , ' Mesoporous LaMnO3+delta perovskite from spray - pyrolysis with superior performance for oxygen reduction reaction and $\mathrm{Zn}$ - air battery ' , Nano Energy , vol. 43 , pp. 81-90 . https://doi.org/10.1016/j.nanoen.2017.11.018

http://hdl.handle.net/10138/306781

https://doi.org/10.1016/j.nanoen.2017.11.018

acceptedVersion

Downloaded from Helda, University of Helsinki institutional repository.

This is an electronic reprint of the original article.

This reprint may differ from the original in pagination and typographic detail.

Please cite the original version. 


\section{Author's Accepted Manuscript}

Mesoporous $\mathrm{LaMnO}_{3+\delta}$ perovskite from spray-pyrolysis with superior performance for oxygen reduction reaction and $\mathrm{Zn}$-air battery

Long Kuai, Erjie Kan, Wei Cao, Marko Huttula, Sami Ollikkala, Taru Ahopelto, Ari-Pekka Honkanen, Simo Huotari, Wenhai Wang, Baoyou Geng

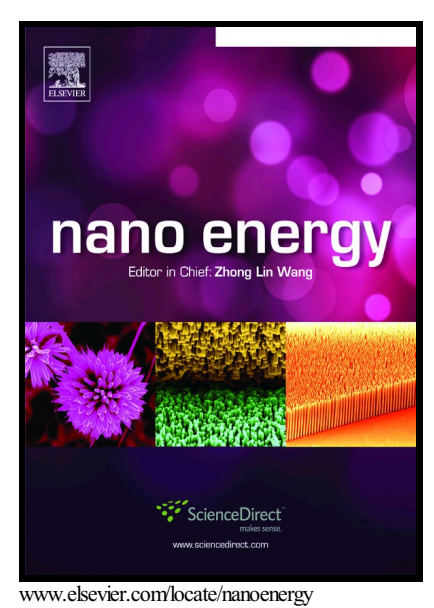

PII: $\quad$ S2211-2855(17)30694-8

DOI: $\quad$ https://doi.org/10.1016/j.nanoen.2017.11.018

Reference: NANOEN2319

To appear in: Nano Energy

Received date: 15 October 2017

Revised date: 4 November 2017

Accepted date: 7 November 2017

Cite this article as: Long Kuai, Erjie Kan, Wei Cao, Marko Huttula, Sami Ollikkala, Taru Ahopelto, Ari-Pekka Honkanen, Simo Huotari, Wenhai Wang and Baoyou Geng, Mesoporous $\mathrm{LaMnO}_{3+\delta}$ perovskite from spray-pyrolysis with superior performance for oxygen reduction reaction and $\mathrm{Zn}$-air battery, Nano Energy, https://doi.org/10.1016/j.nanoen.2017.11.018

This is a PDF file of an unedited manuscript that has been accepted for publication. As a service to our customers we are providing this early version of the manuscript. The manuscript will undergo copyediting, typesetting, and review of the resulting galley proof before it is published in its final citable form. Please note that during the production process errors may be discovered which could affect the content, and all legal disclaimers that apply to the journal pertain. 


\title{
Mesoporous $\mathrm{LaMnO}_{3+\delta}$ perovskite from spray-pyrolysis with
} superior performance for oxygen reduction reaction and $\mathbf{Z n}-$ air

\section{battery}

Long Kuai $^{\mathrm{a}, \mathrm{b}}$, Erjie Kan ${ }^{\mathrm{a}, \mathrm{b}}$, Wei Cao ${ }^{\mathrm{c}}$, Marko Huttula ${ }^{\mathrm{c}}$, Sami Ollikkala ${ }^{\mathrm{d}}$, Taru Ahopelto ${ }^{\mathrm{d}}$,

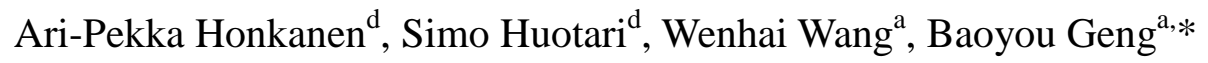

${ }^{a}$ College of Chemistry and Materials Science, The Key Laboratory of Functional Molecular Solids, Ministry of Education, Anhui Laboratory of Molecular-Based Materials, Center for Nano Science and Technology, Anhui Normal University. No.1 Beijing East Road, Wuhu, 241000, P. R. China.

${ }^{\mathrm{b}}$ School of Biological and Chemical Engineering, Anhui Polytechnic University, Middle Beijing Road, Wuhu, 241000, P. R. China.

${ }^{\mathrm{c}}$ Nano and Molecular Systems Research Unit, University of Oulu, P.O. Box 3000, FIN-90014 Oulu, Finland.

${ }^{\mathrm{d}}$ Department of Physics, University of Helsinki, PO Box 64, FI-00014 Helsinki, Finland.

*Corresponding author.bygeng@mail.ahnu.edu.cn

\begin{abstract}
Oxygen reduction reaction (ORR) is the key reaction in various electrochemical energy devices. This work reports an inexpensive mesoporous $\mathrm{LaMnO}_{3+\delta}$ perovskite for ORR with remarkable activity, synthesized by a facile aerosol-spray assisted approach. The mesoporous $\mathrm{LaMnO}_{3+\delta}$ material shows a factor of 3.1 higher activity (at $0.9 \mathrm{~V}$ vs. RHE) than $\mathrm{LaMnO}_{3}$ obtained from co-precipitation method (LMO-CP).
\end{abstract}




\section{ACCEPTED MANUSCRIPT}

Based on results of x-ray absorption near-edge spectroscopy (XANES), x-ray photoelectron spectroscopy (XPS) and Brunauer-Emmett-Teller (BET) analysis, we conclude that the chemical state of surface Mn and the high surface area are the sources to the notably enhanced activity. The study of $\mathrm{Zn}$-air batteries device further confirmed a $\mathrm{Pt} / \mathrm{C}$ comparable performance in the practical devices with the novel mesoporous $\mathrm{LaMnO}_{3+\delta}$ catalyst, where the power density at $200 \mathrm{~mA} / \mathrm{cm}^{2}$ is only $2.1 \%$ lower than in the battery with same-loaded Pt/C catalyst. Therefore, the high mass activity and low-cost of $\mathrm{Mn} / \mathrm{La}$ may make $\mathrm{LaMnO}_{3+\delta}$ further approach to the application of electrochemical devices.

\section{Graphical abstract}

A device-feasible and Earth-abundant $\mathrm{LaMnO}_{3+\delta}$ electrocatalyst is obtained for ORR and $\mathrm{Zn}$-air batteries. Contributed by the surface oxidation state of $\mathrm{Mn}$ and high specific surface area, it displayed a commercial Pt/C comparable performance.

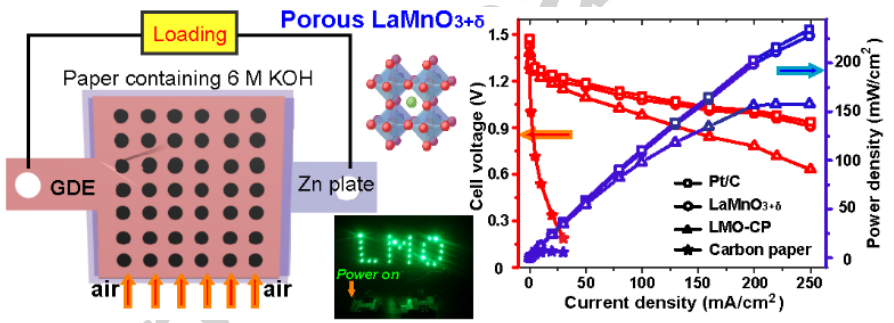

Keywords: $\mathrm{LaMnO}_{3+\delta}$; mesoporous; oxidation state; oxygen reduction reaction;

Zn-air battery

\section{Introduction}

Driven by the increasing environmental and energy-related problems, there is a considerable interest in novel sustainable and green power sources[1,2]. Due to the environment-friendly power generation form and high energy/power density, the 


\section{ACCEPTED MANUSCRIPT}

electrochemical energy devices, such as polymer electrolyte membrane fuel cells and rechargeable metal-air batteries, have attracted the widespread attention of scientists[3,4]. Oxygen reduction reaction (ORR), the cathodic process of electrochemical energy cells, determines the overall device performance due to its sluggish 4e pathway and high reaction barriers[5-7]. In general, precious Pt group (PG) catalysts are demanded to obtain high ORR kinetics[8,9]. Limited by their high cost and ultra-low abundance on Earth, scientists are therefore doing their best to search for inexpensive catalysts with a performance that would approach that of PG catalysts, and many excellent candidates have been investigated. Typically, heteroatom-doped carbon nanomaterials[10-15], metal oxides/N-rGO hybrids[16-19], transition metal carbide/heteroatom-doped carbon[20,21], and perovskites[22-29] have been extensively studied during the recent years.

Among the non-Pt group (NPG) catalysts, perovskites $\left(\mathrm{ABO}_{3}\right)$ with high conductivity have gained much attention since they were found to possess excellent intrinsic activity for oxygen catalysis[24,30], typically for $\mathrm{LaMnO}_{3+\delta}$ that has the currently most comparable intrinsic activity to the commercial Pt/C catalyst. It is well known that the apparent ORR activity of $\mathrm{LaMnO}_{3+\delta}$ is highly sensitive to the preparation method relative to both the state of Mn and specific surface area[28-30]. For example, the conventional solid-state reaction with high reaction temperature always leads to the particles' size as large as hundreds of nanometers[30-34], which results in an inferior apparent activity less than $1.0 \mathrm{~A} / \mathrm{g}$ (at $0.9 \mathrm{~V} v s$. RHE), although the materials have a high intrisic activity. Other routes like the co-precipitation 
method has been developed to efficiently prepare perovskite nanoparticles with surface area of $5 \sim 30 \mathrm{~m}^{2} / \mathrm{g}[35,36]$. Unfortunately, the products are mainly of a lower-active phase and the apparent activity also remains low level. Currently, the appratent activity of $\mathrm{LaMnO}_{3+\delta}$ catalysts is still far from the commercial $\mathrm{Pt} / \mathrm{C}$ level. Therefore, it is still desirable to prepare nanosized $\mathrm{LaMnO}_{3+\delta}$ with preferred phase for high efficiency ORR.

In this work, we present a mesoporous $\mathrm{LaMnO}_{3+\delta}$ catalyst with commercial $\mathrm{Pt} / \mathrm{C}$ comparable performance by an efficient nitrate spray-pyrolysis method (NSPM). The as-obtained mesoporous $\mathrm{LaMnO}_{3+\delta}$ shows a preferred rhombohedral phase with a dominant surface $\mathrm{Mn}^{4+}$ fraction and a high specific surface area of $24.8 \mathrm{~m}^{2} / \mathrm{g}$, which contributes a factor of 3.1 higher activity than that of $\mathrm{LaMnO}_{3}$ nanoparticles prepared by co-precipitation (LMO-CP). We confirm further with a constructed $\mathrm{Zn}$-air battery device that the performance is comparable to that of $\mathrm{Pt} / \mathrm{C}$ in practical devices of the mesoporous $\mathrm{LaMnO}_{3+\delta}$ catalyst. Therefore, as an excellent NPG catalysts for ORR, the high activity and low-cost of $\mathrm{Mn} / \mathrm{La}$ may make mesoporous $\mathrm{LaMnO}_{3+\delta}$ a novel further approach for an application in electrochemical devices.

\section{Experimental Section}

\subsection{Chemicals and Materials}

All the chemicals were of analytical grade, and used as received without further purification. The metal salts, $\mathrm{NaOH}(\mathrm{AR})$, and $\mathrm{KOH}(99.99 \%)$ were bought from Aladdin. The triblock polymer Pluronic P-123 $\left(\mathrm{EO}_{20} \mathrm{PO}_{70} \mathrm{EO}_{20}\right)$ was purchased from Sigma. The Pt/C catalyst (20\% Pt loading) and Nafion (5 wt.\%) solution was obtained 


\section{ACCEPTED MANUSCRIPT}

from Dupont Co. Ltd. The high-purity water used in this study had a resistance $>18$ $\mathrm{M} \Omega$.

\subsection{Synthesis of Porous $\mathrm{LaMnO}_{3+\delta}$ Microspheres}

The devices and method are similar to our previous work. Typically, 1 mmolMn( $\left(\mathrm{NO}_{3}\right)_{2}, 1 \mathrm{mmol} \mathrm{La}\left(\mathrm{NO}_{3}\right)_{3}$ and $0.25 \mathrm{~g} \mathrm{P} 123$ was dissolved in $20 \mathrm{~mL}$ ethanol. The solution was sprayed by a household ultrasonic humidifier (1.7 MHz, $35 \mathrm{~W})$. The generated mist was drawn into a glass tube in a tube furnace $(67 \mathrm{~cm}$, pre-heated to $480{ }^{\circ} \mathrm{C}$ ) by a vacuum pump. The products were collected with a filter paper. The porous products were obtained after calcination in air at $700{ }^{\circ} \mathrm{C}$ for $4 \mathrm{~h}$ at a heating rate of $5{ }^{\circ} \mathrm{C} / \mathrm{min}$.

The porous $\mathrm{LaNiO}_{3}, \mathrm{LaCoO}_{3}$, and $\mathrm{LaCo}_{0.8} \mathrm{Fe}_{0.2} \mathrm{O}_{3}$ were prepared with the same method except that the calcination temperature was $600{ }^{\circ} \mathrm{C}$. For the synthesis of $\mathrm{LaNiO}_{3}$, the calcination is under $\mathrm{O}_{2}$ (purity>99.4\%) flow. $\mathrm{La}_{0.5} \mathrm{Sr}_{0.5} \mathrm{CoO}_{3-\delta}$ and $\mathrm{La}_{0.5} \mathrm{Sr}_{0.5} \mathrm{Co}_{0.8} \mathrm{Fe}_{0.2} \mathrm{O}_{3}$ are obtained by calcination at $800{ }^{\circ} \mathrm{C}$.

\subsection{Synthesis of $\mathrm{LaMnO}_{3}$ Nanoparticles (LMO-CP)}

The $\mathrm{LaMnO}_{3}$ nanoparticles are prepared by a co-precipitation method.[36] 1 $\operatorname{mmolMn}\left(\mathrm{NO}_{3}\right)_{2}$ and $1 \mathrm{mmol} \mathrm{La}\left(\mathrm{NO}_{3}\right)_{3}$ were dissolved in $10 \mathrm{~mL}$ water. $3 \mathrm{~mL}$ of $1.7 \mathrm{M}$ $\mathrm{NaOH}$ solution was subsequently added. The precipitation was washed, collected, dried and finally calcined at $700{ }^{\circ} \mathrm{C}$ for $8 \mathrm{~h}$ in air with a heating rate of $5{ }^{\circ} \mathrm{C} / \mathrm{min}$. 


\subsection{Characterization}

The samples were characterized by X-ray diffraction (XRD; Philips X'Pert with $\mathrm{Cu}$ $\mathrm{K}_{\alpha 1}$ radiation $(\lambda=0.154056 \mathrm{~nm})$ ), scanning electron microscopy (SEM; Hitachi $\mathrm{S}$ 4800) with $5 \mathrm{kV}$ accelerating voltage, transmission electron microscopy (TEM) and high-resolution TEM (HRTEM) (Tecnai G2 20 S-TWIN) with $200 \mathrm{kV}$ accelerating voltage. The elements' EDX mapping was performed by SEM (Hitachi S-5500) with $30 \mathrm{kV}$ accelerating voltage. X-ray photoelectron spectroscopy (XPS) experiments were conducted on ESCALAB 250 (America) at $15 \mathrm{kV}$. The Brunauer-EmmettTeller (BET) specific surface areas and Barrett-Joyner-Halenda (BJH) pore size distributions were measured and analyzed by $\mathrm{N}_{2}$ sorption isotherms $(77 \mathrm{~K})$ with 3 Flex Surface Characterization Analyzer (Micromeritics, America).

\section{X-ray Absorption Spectroscopy Measurements:}

The XANES measurements were performed on a home-laboratory spectrometer based on a spherically bent $\mathrm{Si}(440)$ and $\mathrm{Si}(531)$ monochromator crystals in the Johann geometry, curvature radius $500 \mathrm{~mm}$.[37] The design is similar to that of Seidler et. al.[38, 39] An x-ray tube with a $\mathrm{Ag}$ anode was used as the photon source $(20 \mathrm{kV}$ voltage and $2 \mathrm{~mA}$ current for Co K edge, and $9 \mathrm{kV} / 10 \mathrm{~mA}$ for the Mn K edge). The monochromated x-rays were focused on a powder sample in front of a $\mathrm{NaI}$ scintillator detector. The detector and monochomator followed the Rowland circle with linear translation motors and a goniometer for the selection of the Bragg angle. 


\section{ACCEPTED MANUSCRIPT}

\section{Electrode Preparation and ORR Measurements:}

The glassy carbon electrode (5 $\mathrm{mm}$ in diameter, Pine Instrument) was polished with first $1-\mu \mathrm{m}$ and then $0.05-\mu \mathrm{m}$ particle-sized $\mathrm{Al}_{2} \mathrm{O}_{3}$ powders. The catalyst ink was prepared by mixing $5 \mathrm{mg}$ catalyst powder, $1 \mathrm{mg}$ carbon (Vucan XC-72, Carbot), 10 $\mu \mathrm{L}$ of 5 wt.\% Nafion (Dupont), $0.66 \mathrm{~mL} \mathrm{H}_{2} \mathrm{O}$ and $0.34 \mathrm{~mL}$ dimethylfomamide (DMF) with assistance of ultrasonic treatment for 5 minutes. $10 \mu \mathrm{L}$ of the catalytic ink was dropped onto the polished glassy carbon electrode and dried naturally. The catalyst loading was $0.25 \mathrm{mg} \mathrm{cm}^{-2}$. For the carbon black modified electrodes, the mass loading was $0.05 \mathrm{mg} \mathrm{cm}^{-2}$. The electrodes with catalyst loadings of 0.125 and $0.05 \mathrm{mg} \mathrm{cm}^{-2}$ were prepared by reducing the amount of active materials.

The ORR measurements were performed in $0.1 \mathrm{M} \mathrm{KOH}$ solution by a three-electrode system with an electrochemistry workstation (CHI 660C), where the $\mathrm{Ag} / \mathrm{AgCl}$ electrode ( $\mathrm{KCl}$ saturated) was used as reference electrode, and Pt plate (1 $\mathrm{cm}^{*} 1 \mathrm{~cm} * 0.02 \mathrm{~cm}$ ) was used as counter electrode. The static cyclic voltammograms $(\mathrm{CVs})$ were recorded under $\mathrm{N}_{2}$ (purity > 99.999\%) and $\mathrm{O}_{2}$ (purity > 99.999\%) saturated $150 \mathrm{~mL}$ of $0.1 \mathrm{M} \mathrm{KOH}$, respectively. The rotating disk (glassy carbon) electrode measurements were performed at the rotating speeds of 400, 625, 900, 1225 and $1600 \mathrm{rpm}$ (Pine Instrument rotator). The rotating ring (Pt)-disk (glassy carbon) electrode (RRDE, 37\% collection efficiency, Pine) measurements were performed at the rotating speed of $1600 \mathrm{rpm}$, and the potential of ring electrode was set at $0.2 \mathrm{~V}(\mathrm{vs}$. $\mathrm{Ag} / \mathrm{AgCl}$ electrode). The current-time curves were recorded at $-0.5 \mathrm{~V}$ (vs. $\mathrm{Ag} / \mathrm{AgCl}$ electrode) at a RDE rotating rate of $1225 \mathrm{rpm}$. All the scanning rates were $10 \mathrm{mV} / \mathrm{s}$. 
The potential was iR-corrected and referenced to reversible hydrogen electrode (RHE), which was calibrated with the peak position of Mn sites in the literature. Consequently, $\mathrm{E}_{\mathrm{RHE}}=\mathrm{E}_{\text {applied }}+0.960-\mathrm{iR}$, where $\mathrm{E}_{\text {applied }}$ is the applied potential vs. $\mathrm{Ag} / \mathrm{AgCl}$ electrode and $\mathrm{R}$ stands for the $\mathrm{Ohm}$ resistance determined by electrochemical impedance spectrum $(\sim 43 \Omega$ in this work, Fig. S1). In this work, dual references $(\mathrm{Ag} / \mathrm{AgCl}$ and $\mathrm{RHE})$ to potential are presented to facilitate the comparison with the result with existing literature, and all the potentials in the results discussion are referenced to RHE except when mentioned specifically.

\section{Zn-Air Battery Assembly and Test:}

A home-built Zn-air battery was assembled with a $\mathrm{Zn}$ plate with diameter of $1.5 \mathrm{~cm}$ as an anode, a catalyst-modified gas diffusion electrode (GDE, PTFE-treated hydrophobic carbon paper) with active area of about $1.0 \mathrm{~cm}^{2}$ as the cathode, and a filter paper as a separator. About $0.3 \mathrm{~mL}$ of $6.0 \mathrm{M} \mathrm{KOH}$ solution was added into the cell as the electrolyte. A metal net was covered on the GDE as the cathode current collector. The loading of active materials in GDEs for all the batteries was about 2 $\mathrm{mg} / \mathrm{cm}^{2}$. For the oxide catalysts, $0.5 \mathrm{mg} / \mathrm{cm}^{2}$ of carbon black (Vucan XC-72, Carbot) was added to increase the conductivity. The resistance of the cell was about $0.8 \Omega$. The cell measurements were performed under the $\mathrm{O}_{2}$ flow with the temperature of about $20{ }^{\circ} \mathrm{C}$. 


\section{ACCEPTED MANUSCRIPT}

\section{Results and Discussion}

\subsection{Synthesis and Characterizations}

The synthesis procedure of mesoporous $\mathrm{LaMnO}_{3+\delta}$ microspheres consists of amorphous precursor preparation and subsequent calcination process. Firstly, the amorphous $\mathrm{LaMnO}_{3}$ precursor was prepared by NSPM as reported in our previous work [40,41]. As illustrated in Fig. 1a, the NSPM process consists of spraying the mother solution (part i, containing $\mathrm{Mn}\left(\mathrm{NO}_{3}\right)_{2}, \mathrm{La}\left(\mathrm{NO}_{3}\right)_{3}$ and Pluronic P-123 $\left(\mathrm{EO}_{20} \mathrm{PO}_{70} \mathrm{EO}_{20}\right)$ ), pyrolysis of nitrates (part ii), and powder collection (part iii). Finally, the mesoporous $\mathrm{LaMnO}_{3+\delta}$ microspheres were obtained by thermal treatment. As shown in the scanning electron microscopy (SEM) image (Fig. 1b), the amorphous $\mathrm{LaMnO}_{3}$ microspheres with sizes of $0.886 \pm 0.300 \mu \mathrm{m}$ are solid and surface-smooth. After calcination for removal of P-123 template, the obtained $\mathrm{LaMnO}_{3+\delta}$ products exhibit typical porous structures with sizes of $0.716 \pm 0.310 \mu \mathrm{m}$ (Fig. 1c). The transmission electron microscopy (TEM) image (Fig. 1d) further presents the detailed porous structure information. The microspheres are assembled by nanoparticles with sizes of $35-60 \mathrm{~nm}$. The pore sizes ranged from 20 to $50 \mathrm{~nm}$. Based on the $\mathrm{N}_{2}$ adsorption-desorption isotherm measurement (Fig. S2a), the mesoporous $\mathrm{LaMnO}_{3+\delta}$ products have a high Brunauer-Emmett-Teller (BET) specific surface area of $24.8 \mathrm{~m}^{2} / \mathrm{g}$ and Barrett-Joyner-Halenda $(\mathrm{BJH})$ pore size centered at $\sim 30 \mathrm{~nm}$ (Fig.S2b), favorable for catalytic active site exposure. Successively, the high-resolution TEM (HRTEM) image (Fig. 1e) shows the lattice spacing of $0.29 \mathrm{~nm}$, which can be indexed to the $\{110\}$ plane. Moreover, the energy-dispersive X-ray 


\section{ACCEPTED MANUSCRIPT}

(EDX) elemental mapping (Fig. 1f) confirms the presence of O, Mn and La elements. Importantly, the O (green), Mn (white) and La (red) elements are found to be well overlapped with each other, suggesting the uniform distribution of $\mathrm{Mn}$ and $\mathrm{La}$ in $\mathrm{LaMnO}_{3+\delta}$. In addition, some other mesoporous perovskite oxides were also prepared by NSPM in this work for meaningful comparison, such as $\mathrm{LaCoO}_{3}(\mathrm{LCO}), \mathrm{LaNiO}_{3}$ (LNO), $\mathrm{La}_{0.5} \mathrm{Sr}_{0.5} \mathrm{CoO}_{3-\delta}(\mathrm{LSCO})$, etc. (Fig. S3)

X-ray powder diffraction (XRD) patterns were performed to analyze the crystalline phase of products. As show in Fig. 2a, only perovskite phase (black) with low crystallization degree was observed when $\mathrm{LaMnO}_{3}$ precursor was calcined at $600{ }^{\circ} \mathrm{C}$ for $4 \mathrm{~h}$. When the temperature was increased to $700{ }^{\circ} \mathrm{C}$, the well-crystallized $\mathrm{LaMnO}_{3+\delta}$ products were obtained (blue). It is interesting that the obtained sample is rhombohedral phase (green, JCPDS NO. 50-299), which is the preferred phase for ORR [29]. Several diffraction peaks split into two peaks (the dashed box) and one weak peak centered at $2 \theta$ of $38.5^{\circ}$ appears (insets). For meaningful comparison, we also prepared the $\mathrm{LaMnO}_{3}$ nanoparticles by co-precipitation (marked as LMO-CP)[36]. The obtained LMO-CP possesses particle sizes 40-70 nm (Fig. S4a, b) and BET specific surface area of $16.4 \mathrm{~m}^{2} / \mathrm{g}$ (Fig. S4c). Different from the mesoporous $\mathrm{LaMnO}_{3+\delta}$ from NSPM, the LMO-CP presents cubic phase (red), and neither peak centered at $2 \theta$ of about $38.5^{\circ}$ nor obvious peak splitting can be observed through its XRD pattern. The XRD patterns of other products obtained from NSPM are also confirmed to be perovskite structure (Fig. S5) after calcination. 
The Mn K-edge X-ray absorption near edge structures (XANES) were investigated to elucidate the differences in the synthetic samples. The XANES spectra of the mesoporous $\mathrm{LaMnO}_{3+\delta}$ (blue) and LMO-CP (red) are depicted in Fig. 2b along with those from the $\mathrm{MnO}$ (black), $\mathrm{Mn}_{3} \mathrm{O}_{4}$ (green), and $\mathrm{MnO}_{2}$ (orange) for comparison purposes. In general, the XANES of the $\mathrm{LaMnO}_{3+\delta}$ resembles the one of the $\mathrm{LaMnO}_{3}$, with clear features of the pre-edge bump at $\sim 6540 \mathrm{eV}$, white line at $6557 \mathrm{eV}$, and a post-edge bump at $6568 \mathrm{eV}$. The white line positions of the two samples stay between these of $\mathrm{MnO}$ and $\mathrm{Mn}_{3} \mathrm{O}_{4}$, but much lower in energy than the one from $\mathrm{MnO}_{2}$, which is consistent to the perovskite phase. No obvious energy shift was found between the samples, indicating a similar Mn oxidation state in the bulk. However, obvious differences are seen at the width of the white line and the height of the pre-edge pumps. Narrowing the main peak refers to the asymmetrisation of the Mn $4 \mathrm{p}$ orbital caused by the rhombohedral phase in the $\mathrm{LaMnO}_{3+\delta}$ rather than the cubic phased matrix, in line with previously reported first-principles evaluations on similar systems [42]. Interestingly, the signature of the $\mathrm{e}_{\mathrm{g}}$ states and its changes can be identified in the K-edge XANES. In the inset of Fig. 2b, clear changes of the pre-edge 'bump' intensity can be seen. This 'bump' bears the hybridizations of the $4 p$ orbitals to the $3 d$ orbitals of the Mn neighboring atoms, yet populating the $3 \mathrm{~d}$ partial density of states, and associating to the transition to the $\mathrm{e}_{\mathrm{g}}$ states [43]. Compared with the LMO-CP, slight decrease of the pump intensity is found in the $\mathrm{LaMnO}_{3+\delta}$, indicating the higher e occupancy. The $\mathrm{LaMnO}_{3+\delta}$ exhibit much higher activity than that of LMO-CP, 
which dissatisfies the result on $\mathrm{e}_{\mathrm{g}}$ electron indicator. Thus, the state of surface $\mathrm{Mn}$ may play more dominant role in the ORR process, which will be discussed later.

X-ray photoelectron spectra (XPS, Fig. 2c, d and S6a) were measured to confirm and compare the surface chemical environment of the as-prepared $\mathrm{LaMnO}_{3+\delta}$ and LMO-CP samples. As shown in the left of Fig. 2c with C1s as internal standard (Fig. S6b) of binding energy $\left(E_{b}\right)$, the binding energy $\left(E_{b}\right)$ peak of Mn2p in rhombohedral $\mathrm{LaMnO}_{3+\delta}(642.13 \mathrm{eV})$ is positively shifted by $0.44 \mathrm{eV}$ compared with LMO-CP (641.69 eV), indicating the higher surface oxidation state of $\mathrm{Mn}$ in $\mathrm{LaMnO}_{3+\delta}$, which is different from that in the bulk determined by XANES. This is not surprising since the effective detection depth of the XPS allows only a surface-state probation while the hard X-rays measures the bulk of the powders. The surface oxygen spectra (right of Fig. 2c) further clarify this. The peaks centered at the lower $\mathrm{E}_{\mathrm{b}}{ }^{\mathrm{O}}$ are assigned to the lattice $\mathrm{O}$ and the ones centered at the higher $\mathrm{E}_{\mathrm{b}}{ }^{\mathrm{O}}$ are corresponded to $-\mathrm{OH}$ [44]. Firstly, there is only a slight $\mathrm{E}_{\mathrm{b}}{ }^{\mathrm{O} s}$ difference $(0.08 \mathrm{eV})$ of $-\mathrm{OH}$ because the Pauling's electronegativity of $\mathrm{H}(2.20)$ is much larger than the electronegativity difference of $\mathrm{Mn}$ between $\mathrm{LaMnO}_{3+\delta}$ and LMO-CP. While, the $\mathrm{E}_{\mathrm{b}}{ }^{\mathrm{O} \text { s }}$ peak for lattice $\mathrm{O}$ of $\mathrm{LaMnO}_{3+\delta}(529.50 \mathrm{eV})$ is positively shifted by extraordinary $0.52 \mathrm{eV}$ than that of LMO-CP (528.98 eV). Moreover, the $\mathrm{E}_{\mathrm{b}}{ }^{\mathrm{O} s \mathrm{~s}}$ peak for lattice $\mathrm{O}$ of $\mathrm{LaMnO}_{3+\delta}$ falls in the region between the $\mathrm{E}_{\mathrm{b}}$ peak in $\mathrm{LaMnO}_{3}(\sim 529 \mathrm{eV})$ [45] and $\mathrm{MnO}_{2}(530 \mathrm{eV})$ [34]. Successively, we made an assignment of the peaks for various oxidation states of surface Mn by fitting the Mn2p spectra (Fig. 2d and Table S1). As a result, the $\mathrm{LaMnO}_{3+\delta}$ possesses a higher proportion of $\mathrm{Mn}^{\mathrm{IV}}(43.4 \%$, left of Fig. 2d) than 
LMO-CP (31.0\%, right of Fig. 2d). Besides, consistent with the previous reports[46], the surface segregation of $\mathrm{La}_{2} \mathrm{O}_{3}$ was also found in the two products where XPS (Table S2) shows that the surface $\mathrm{Mn} / \mathrm{La}$ ratio is 0.54 and 0.78 in $\mathrm{LaMnO}_{3+\delta}$ and LMO-CP, respectively. The larger $\mathrm{La}_{2} \mathrm{O}_{3}$ segregation in rhombohedral $\mathrm{LaMnO}_{3+\delta}$ surface may be responsible for the larger surface $\mathrm{Mn}^{4+}$ proportion.

\subsection{Electrocatalytic Performance toward ORR in Alkaline Media}

The electrocatalytic activity of the mesoporous $\mathrm{LaMnO}_{3+\delta}$ and $\mathrm{LMO}-\mathrm{CP}$ toward ORR was evaluated in an $\mathrm{O}_{2}$-saturated $0.1 \mathrm{M} \mathrm{KOH}$ solution. The carbon black and commercial Pt/C catalysts with identical electrochemical active surface area of 46.0 $\mathrm{m}^{2} / \mathrm{g}$ (Fig. S7) were also investigated for meaningful comparison. Besides, several repeated measurements with graphite rod instead of Pt plate as counter electrode were also performed to exclude the possible effect of counter electrode on the results (Fig. S8). As displayed in Fig. 3a, obvious $\mathrm{O}_{2}$ reduction peaks are found for all these samples. As presented in Table 1, the ORR peak for $\mathrm{LaMnO}_{3+\delta}$ (red) is centered at $0.872 \mathrm{~V}$ with peak current density $\left(j_{\mathrm{p}}\right)$ of $0.75 \mathrm{~mA} / \mathrm{cm}^{2}$, which is $27 \mathrm{mV}$ higher than LMO-CP (pink, $0.845 \mathrm{~V}$ with $j_{\mathrm{p}}$ of $0.57 \mathrm{~mA} / \mathrm{cm}^{2}$ ). Furthermore, the activity of $\mathrm{LaMnO}_{3+\delta}$ is even comparable to the same mass-loaded commercial Pt/C catalyst, whose peak potential is just $25 \mathrm{mV}$ lower than that of $\mathrm{Pt} / \mathrm{C}$ (green, $0.897 \mathrm{~V}$ ). Successively, the ORR polarization curves on rotating disk electrode (RDE) (Fig. 3b) were recorded at a rotating speed of $1600 \mathrm{rpm}$. Herein, all the ORR polarization curves have been corrected by removing the background currents that measured under the $\mathrm{N}_{2}$-saturated electrolyte. We also present the ORR polarization of carbon black, 


\section{ACCEPTED MANUSCRIPT}

which suggests that the activity of carbon black (blue) used in catalyst ink can be negligible for discussing the activity of oxides. Apart from the carbon black, all the limiting current densities $\left(j_{\mathrm{L}}\right)$ of porous $\mathrm{LaMnO}_{3+\delta}($ red), LMO-CP (pink) and $\mathrm{Pt} / \mathrm{C}$ catalysts (green) are highly close to the theoretical $j_{\mathrm{L}}\left(5.75 \mathrm{~mA} / \mathrm{cm}^{2}\right.$ at $\left.1600 \mathrm{rpm}\right)$, indicating a near $4 \mathrm{e}$ ORR pathway. While, the half-wave potential $\left(\mathrm{E}_{1 / 2}\right)$ for the porous $\mathrm{LaMnO}_{3+\delta}\left(\mathrm{E}_{1 / 2}=0.852 \mathrm{~V}\right)$ is $50 \mathrm{mV}$ positive than $\mathrm{LMO}-\mathrm{CP}\left(\mathrm{E}_{1 / 2}=0.802 \mathrm{~V}\right)$. Moreover, the activity of porous $\mathrm{LaMnO}_{3+\delta}$ is highly approaching to that of the same-loaded commercial Pt/C catalyst: The $\mathrm{E}_{1 / 2}$ for the porous $\mathrm{LaMnO}_{3+\delta}$ is just 36 $\mathrm{mV}$ lower than $\mathrm{Pt} / \mathrm{C}$, further indicating a superior ORR catalytic activity of $\mathrm{LaMnO}_{3+\delta}$ with relatively low cost. Besides, we also studied the ORR electrocatalytic performance of the as-prepared porous $\mathrm{LaNiO}_{3}$ and $\mathrm{LaCoO}_{3}$. However, their activity is far worse than that of the $\mathrm{LaMnO}_{3+\delta}$ (Fig. S9) in the same condition.

The electron transfer number (n), directly associated with the ORR pathway, is used to evaluate the ORR efficiency. The Koutecky-Levich equation $[47,48]$ (Eq. (1) and (2)) is used to estimate the n value.

$j^{-1}=j_{\mathrm{k}}^{-1}+j_{\mathrm{d}}^{-1}$

$j_{\mathrm{d}}=0.62 \mathrm{nFC}_{0} \mathrm{D}_{0}^{2 / 3} v^{-1 / 6} \omega^{1 / 2}$

In the Koutecky-Levich equation, the $j$ is the measured Faradic current density, $j_{\mathrm{k}}$ is the kinetic-limiting current density, $j_{\mathrm{d}}$ is the diffusion-limiting current at the RDE rotating speed of $\omega(\mathrm{rad} / \mathrm{s}), \mathrm{n}$ is the transferred electron number, $\mathrm{F}$ is the Faraday constant $(96485 \mathrm{C}), \mathrm{C}_{0}$ is the bulk concentration of dissolved $\mathrm{O}_{2}\left(1.21 \mathrm{~mol} / \mathrm{m}^{3}\right.$ in 0.1 $\mathrm{M} \mathrm{KOH}), \mathrm{D}_{0}$ is $\mathrm{O}_{2}$ diffusion coefficiency $\left(1.87 \times 10^{-9} \mathrm{~m} / \mathrm{s}\right.$ in $\left.0.1 \mathrm{MKOH}\right), v$ is 
kinematic viscosity of electrolyte $\left(1 \times 10^{-6} \mathrm{~m}^{2} / \mathrm{s}\right.$ for $\left.0.1 \mathrm{M} \mathrm{KOH}\right)$ and $\omega$ is the angular frequency of RDE rotation. Given the above conditions, there is a linear relationship between $j^{-1}$ and $\omega^{-1 / 2}$. Fig. 3c shows the Koutecky-Levich analysis of the $j$ with different rotation rates of 400, 625, 900, 1225 and $1600 \mathrm{rpm}$ (Fig. S10) at $0.5 \mathrm{~V}$. When performing the Koutecky-Levich analysis, the Faradic $j$ was corrected by the removal of background current measured under $\mathrm{N}_{2}$ atmosphere (the black lines in Fig. S10). According to the Koutecky-Levich equation, the slope of $j^{-1}$ function of $\omega^{-1 / 2}$ is associated with the $\mathrm{n}$ value of ORR process. The slopes of mesoporous $\mathrm{LaMnO}_{3+\delta}$, LMO-CP and Pt/C catalysts are calculated to be $2.201 \pm 0.014,2.265 \pm 0.017$ and $2.176 \pm 0.024 \mathrm{~cm}^{2} \mathrm{~mA}^{-1} \mathrm{~s}^{-1 / 2}$. Given the $\mathrm{n}$ value for $\mathrm{Pt} / \mathrm{C}$ is 4 , the $\mathrm{n}$ values for $\mathrm{LaMnO}_{3+\delta}$ and LMO-CP is 3.95 and 3.84, indicating the 4e pathway for both mesoporous $\mathrm{LaMnO}_{3+\delta}$ catalyst and LMO-CP.

To discuss the mass activity and intrinsic activity of mesoporous $\mathrm{LaMnO}_{3+\delta}$ and LMO-CP, an electrocatalysis with different catalyst loadings was performed (Fig. S11). The following activity was based on the measurements with catalysts loading of $0.05 \mathrm{mg} \mathrm{cm}^{-2}$. First, we discuss the mass activity $\left(j_{\mathrm{m}}\right)$, which is critical to the device's performance and determined by both the intrinsic activity and specific surface area. The potential-dependent $j_{\mathrm{m}}$ plots of mesoporous $\mathrm{LaMnO}_{3+\delta}$, LMO-CP and Pt/C catalysts are displayed in Fig. 3d. The $j_{\mathrm{m}}$ of $\mathrm{Pt} / \mathrm{C}$ catalyst is normalized by the loading of metallic Pt $(2 \mu \mathrm{g})$. Herein, we discuss $j_{\mathrm{m}}$ at $0.9 \mathrm{~V}$ ( $v s$. RHE). The $j_{\mathrm{m}}$ of mesoporous $\mathrm{LaMnO}_{3+\delta}$ (red) reaches extraordinary $2.83 \pm 0.20 \mathrm{~A} / \mathrm{g}_{\text {oxide, }}$, which is 3.1 times that of LMO-CP $\left(0.90 \pm 0.10 \mathrm{~A} / \mathrm{g}_{\text {oxide, }}\right.$ pink $)$. To the best of our knowledge, the mass activity 


\section{ACCEPTED MANUSCRIPT}

in this work is notably higher than the reported best values of $\mathrm{LaMnO}_{3+\delta}$ catalysts $[33$, $49,50]$, and it is even superior to some carbon-based materials with ultralarge specific surface areas (Table S3). Furthermore, it is highly worthy to mention that the $j_{\mathrm{m}}$ of $\mathrm{LaMnO}_{3+\delta}$ has reached $4.5 \%$ of metallic Pt $\left(63.05 \pm 4.45 \mathrm{~A} / \mathrm{g}_{\mathrm{Pt}}\right.$, green). In general, the $\mathrm{O}_{2}$ mass transport potential loss can be negligible when the catalyst film thickness is less than $20 \mu \mathrm{m}[51,52]$. We assume the $0.4 \mathrm{mg}_{\mathrm{Pt}} / \mathrm{cm}^{2}$ of $\mathrm{Pt} / \mathrm{C}$ catalyst is used to generate electric power. With the mesoporous $\mathrm{LaMnO}_{3+\delta}$, a loading of $8.9 \mathrm{mg}_{\text {oxide }} / \mathrm{cm}^{2}$ is required to obtain the same cathode performance. Considered the density of $\sim 7$ $\mathrm{g} / \mathrm{cm}^{3}$ of $\mathrm{LaMnO}_{3+\delta}$ and $50 \%$ porosity of catalyst film [46], the corresponding catalyst film thickness is $\sim 24 \mu \mathrm{m}$, where the $\mathrm{O}_{2}$ diffusion potential loss almost can be ignored. Moreover, the much more earth abundance of $\mathrm{Mn}(950 \mathrm{ppm})$ and $\mathrm{La}(32 \mathrm{ppm})$ than $\mathrm{Pt}$ (0.003 ppm) [48] makes mesoporous $\mathrm{LaMnO}_{3+\delta}$ to be a potential commercial catalyst.

As for the intrinsic activity, the $j$ was normalized by the oxides area based on the BET surface areas. Consequently, the intrinsic activity (at $0.9 \mathrm{~V} v s$. RHE) of mesoporous $\mathrm{LaMnO}_{3+\delta}$ from NSPM $\left(11.5 \mu \mathrm{A} / \mathrm{cm}^{2}{ }_{\text {oxide }}\right)$ is 2.1 -fold better than that $(5.5$ $\mu \mathrm{A} / \mathrm{cm}^{2}{ }_{\text {oxide }}$ ) of LMO-CP. We propose that the enhanced intrinsic activity stems from the surface state of Mn, although Shao-Horn et al.'s work suggest that the activity peak will appear at the $\mathrm{e}_{\mathrm{g}}$-filling slightly lower than 1 for $\mathrm{LaMnO}_{3+\delta}$ according to the "volcano shape" relationship between ORR activity and $\mathrm{e}_{\mathrm{g}}$-filling of $\mathrm{ABO}_{3}$ perovskites[30]. However, the present XANES results show that the $\mathrm{e}_{\mathrm{g}}$-filling of $\mathrm{LaMnO}_{3+\delta}$ bulk from NSPM is comparable or even slightly higher than LMO-CP. Thus, the bulk $e_{\mathrm{g}}$-filling contributes less dominantly compared to the surface state of 


\section{ACCEPTED MANUSCRIPT}

Mn because the electrocatalysis is more sensitive to the surface chemical environment instead of that in the bulk.

Beyond the activity issue, electrocatalytic stability is also a critical factor to evaluate the materials. Herein, the long-time continuous ORR tests were carried out to explore the durability of the mesoporous $\mathrm{LaMnO}_{3+\delta}$ and $\mathrm{Pt} / \mathrm{C}$ catalysts. As displayed in Fig. 3e, the mesoporous $\mathrm{LaMnO}_{3+\delta}$ (red) exhibits better catalytic endurance than commercial Pt/C (black) catalyst. In addition, the catalytic endurance toward fuel crossover effect is an important factor to evaluate an ORR catalyst. Herein, we investigated the $\mathrm{CH}_{3} \mathrm{OH}$-tolerance of catalysts as a case study. According to the potential change after injection of absolute $\mathrm{CH}_{3} \mathrm{OH}$ into the electrolyte solution (The final concentration of $\mathrm{CH}_{3} \mathrm{OH}$ is 1.0 M.), as shown in Fig. S12, little negative shift of potential for $\mathrm{LaMnO}_{3+\delta}$ (red) was observed after $\mathrm{CH}_{3} \mathrm{OH}$ was introduced. This result undoubtedly suggests an excellent $\mathrm{CH}_{3} \mathrm{OH}$-tolerance.

\subsection{RRDE Study and Potential Mechanism Discussion}

The rotating ring-disk electrode (RRDE) tests were carried out to further study the ORR process of mesoporous $\mathrm{LaMnO}_{3+\delta}$ catalyst. As shown in Fig. 4a, compared with the LSVs in $\mathrm{N}_{2}$-saturated electrolyte, the ring currents relative to peroxide $\left(\mathrm{HO}_{2}{ }^{-}\right)$ yield were detected for both $\mathrm{LaMnO}_{3+\delta}$ (red) and LMO-CP (green) catalysts along with the ORR process in $\mathrm{O}_{2}$-saturated electrolyte. However, the ring current is about two orders of magnitude lower than the disk current, indicating the high efficiency of ORR. The potential-dependent $\mathrm{HO}_{2}^{-}$yields and $\mathrm{n}$ values were obtained directly from the RRDE test results based on the Eq. (3) and (4)[18, 54]. 


$$
\begin{aligned}
& \left(\mathrm{HO}_{2}^{-}\right) \%=200 \times \frac{\mathrm{i}_{\text {ring }} / \mathrm{N}}{\mathrm{i}_{\text {disk }}+\mathrm{i}_{\text {ring }} / \mathrm{N}} \\
& \mathrm{n}=4 \times \frac{\mathrm{i}_{\text {disk }}}{\mathbf{i}_{\text {disk }}+\mathrm{i}_{\text {ring }} / \mathrm{N}}
\end{aligned}
$$

Where the $i_{\text {disk }}$ and $i_{\text {ring }}$ are the measured Faradic currents in the corresponding disk and ring electrodes, $\mathrm{N}$ is the collection efficiency of ring electrode $(0.37)$, and $\mathrm{n}$ is the electron transfer number. As for the calculation of $\mathrm{n}$ value and $\mathrm{HO}_{2}^{-}$yields, both the ring and disk current are background corrected by taking off the currents measured under $\mathrm{N}_{2}$ atmosphere. As displayed Fig. $\mathbf{4 b}$, we can find that both $\mathrm{n}$ values (blue) and $\mathrm{HO}_{2}^{-}$yield (pink) plots consist 3 parts. In the first potential region before $0.70 \mathrm{~V}$, for both $\mathrm{LaMnO}_{3+\delta}$ and $\mathrm{LMO}-\mathrm{CP}$, the $\mathrm{n}$ values are $\sim 3.99$, but they are all decreased to $\sim 3.95$ in the part with potential lower than $\sim 0.6 \mathrm{~V}$. Based on the measured $\mathrm{n}$ values and $\mathrm{HO}_{2}{ }^{-}$yield, the ORR process on $\mathrm{LaMnO}_{3}-\mathrm{NSPM}$ and LMO-CP all follows the 4e pathway. As for the decreased n number in the potential lower than $0.7 \mathrm{~V}$, the carbon addition may be responsible. According to Savinovaet al.'s work [32, 33], carbon component plays an important role in the ORR process by accelerating the $\mathrm{H}_{2} \mathrm{O}_{2}$ formation, leading to the high $\mathrm{H}_{2} \mathrm{O}_{2}$ yield.

There are two couples of redox pairs in $\mathrm{LaMnO}_{3}$ surface [55], namely, $\mathrm{Mn}^{3+} / \mathrm{Mn}^{4+}$ and $\mathrm{Mn}^{2+} / \mathrm{Mn}^{3+}$ redox couples. According to the CVs (Fig. 3a) of $\mathrm{LaMnO}_{3+\delta}$ and LMO-CP under $\mathrm{N}_{2}$ atmosphere, the conversion of $\mathrm{Mn}^{4+}$ to $\mathrm{Mn}^{3+}$ appears between 0.75 and $1.0 \mathrm{~V}$, and $\mathrm{Mn}^{3+}$ conversion to $\mathrm{Mn}^{2+}$ starts at the potential after $0.7 \mathrm{~V}$. The $\mathrm{Mn}^{4+} / \mathrm{Mn}^{3+}$ conversion peak current of mesoporous $\mathrm{LaMnO}_{3}$ from NSPM is larger than that of $\mathrm{LMO}-\mathrm{CP}$, indicating more $\mathrm{Mn}^{4+}$ in $\mathrm{LaMnO}_{3+\delta}$ surface. Meanwhile, it is at 
this stage, the potential region of $\mathrm{Mn}^{4+}$ reduction, that the activity of $\mathrm{LaMnO}_{3+\delta}$ surpasses that of LMO-CP rapidly. Many reports have suggested that the ORR activity of Mn-based perovskites is highly dependent of the surface Mn oxidation state $[32,46,56]$. The mixed $\mathrm{Mn}^{3+} / \mathrm{Mn}^{4+}$ surface is critical to obtain fast ORR kinetics. In addition, according to the XPS result suggests the $\mathrm{LaMnO}_{3+\delta}$ from NSPM possesses more surface $\mathrm{Mn}^{4+}$ proportion (43.4\%) than that in LMO-CP (31\%). Therefore, the notably surface $\mathrm{Mn}^{4+}$ is the source to the higher pristine activity, which is well consistent with recent reports [46, 48].

\subsection{Device Performance of Zn-air Batteries}

To evaluate the feasibility and performance in a practical device using the obtained mesoporousLaMnO${ }_{3+\delta}$ catalyst, we built a $\mathrm{Zn}$-air battery. As shown in Fig. 5a, the battery consists of Zn plate as anode, catalyst-modified gas diffusion electrode (GDE) as cathode, and 6.0 $\mathrm{M} \mathrm{KOH}$ as electrolyte. The active area of electrode is about 1.0 $\mathrm{cm}^{2}$. The assembly of $\mathrm{Zn}$-air batteries with commercial $\mathrm{Pt} / \mathrm{C}$ and LMO-CP catalysts is the same. All the catalyst loading on the GDE for the batteries is $2.0 \mathrm{mg} / \mathrm{cm}^{2}$. For comparison, the battery with bare carbon paper as the cathode was also investigated.

Fig. 5b presents the I-V (red) and I-P (blue) plots of our batteries. As displayed in Table 1, the open-circuit voltage of cell with mesoporous $\mathrm{LaMnO}_{3+\delta}$ catalyst is $1.43 \mathrm{~V}$, which is slightly lower than that of with $\mathrm{Pt} / \mathrm{C}(1.47 \mathrm{~V})$. It is worth to mention that the cell voltages and power densities of the batteries with $\mathrm{LaMnO}_{3+\delta}$ catalyst is highly approaching to that of with $\mathrm{Pt} / \mathrm{C}$ catalyst. Moreover, the difference is still small even 
the current density is increased to hundreds of milliampere per square centimeter. For example, the power density at $200 \mathrm{~mA} / \mathrm{cm}^{2}$ is $198.6 \mathrm{~mW} / \mathrm{cm}^{2}$, which is only $2.1 \%$ lower than the battery with same-loaded $\mathrm{Pt} / \mathrm{C}$ catalyst $\left(202.8 \mathrm{~mW} / \mathrm{cm}^{2}\right)$. However, considering the practical application, the cost of $\mathrm{LaMnO}_{3+\delta}$ catalyst is much lower than commercial Pt/C. As for the battery with LMO-CP catalyst, the open-circuit voltage is only $1.38 \mathrm{~V}$, slightly lower than that with the $\mathrm{LaMnO}_{3+\delta}$ catalyst. However, the voltage and power density difference are obviously larger and larger with the increase of current density. This finding is well consistent with ORR polarization study, and supports the conclusion of RRDE study that the $\mathrm{Mn}^{3+} / \mathrm{Mn}^{4+}$ redox pair is more dominant for $\mathrm{LaMnO}_{3+\delta}$. Besides, the performance of the cell with bare carbon paper is negligible in comparison with all the batteries with catalyst-modified cathode. Furthermore, Fig. 5c vividly displays the digital photos of "LMO"-shaped pattern assembled by 30 light-emitting diodes (LED, nominal power: $\sim 30 \mathrm{~mW}$ ), which were powered by two tandem home-made $\mathrm{Zn}$-air batteries with $\mathrm{LaMnO}_{3+\delta}$ as catalyst. A bright and continuous green emission was observed when the LEDs were powered on. Thus, the obtained $\mathrm{LaMnO}_{3+\delta}$ catalyst can produce high device performance, such as Zn-air batteries.

\section{Conclusion}

In summary, we present the preparation of device-feasible non-precious mesoporous $\mathrm{LaMnO}_{3+\delta}$ catalysts by NSPM with superior ORR activity. Contributed by the abundant surface $\mathrm{Mn}^{4+}$, a large specific surface area and mesoporous structure, the obtained mesoporous $\mathrm{LaMnO}_{3+\delta}$ displayed is 3.1-fold better than that for the $\mathrm{LaMnO}_{3}$ 
catalystfrom co-precipitation method. It is a new benchmark for the $\mathrm{LaMnO}_{3}$-based perovskite catalysts for ORR in alkaline media. Moreover, the mass activity reaches $22.5 \%$ of commercial $\mathrm{Pt} / \mathrm{C}$ catalyst and correspongding $4.5 \%$ of metallic $\mathrm{Pt}$ while the earth-abundance of La and Mn is 4 5 orders of magnitude higher. The device study of home-built $\mathrm{Zn}$-air batteries further confirmed the feasibility and $\mathrm{Pt} / \mathrm{C}$ comparable performance in the practical device using the obtained mesoporous $\mathrm{LaMnO}_{3+\delta}$ as catalyst. This work demonstrates the feasibility of developing mesoporous $\mathrm{LaMnO}_{3+\delta}$ materials as high efficiency ORR electrocatalysts.

\section{Acknowledgements}

This work was supported by the National Natural Science Foundation of China (21271009, 21471006), the Natural Science Foundation of Anhui Provincial Education Department (KJ2017A111), the Programs for Science and Technology Development of Anhui Province (1501021019). W. C. and M. H. acknowledge EU Regional Development Fund and Council of Oulu Region. S. O., T. A., A.-P. H. and S. H. were supported by the Academy of Finland (project 1295696).

\section{Appendix A. Supplementary material}

\section{References}

[1] M. Armand, J. M. Tarascon, Building better batteries, Nature 451 (2008) 652-657. 


\section{ACCEPTED MANUSCRIPT}

[2] J. Jiang, Y. Y. Li, J. P. Liu, X. T. Huang, C. Z. Yuan, X. W. Lou, Recent advances in metal oxide-based electrode architecture design for electrochemical energy storage, Adv. Mater. 24 (2012) 5166-5180.

[3] B. C. H. Steele, A. Heinzel, Materials for fuel-cell technologies, Nature 414 (2001) 345-352.

[4] F. Y. Cheng, J. Chen, Metal-air batteries: from oxygen reduction electrochemistry to cathode catalysts, Chem. Soc. Rev. 41 (2012) 2172-2192.

[5] V. R. Stamenkovic, B. Fowler, B. S. Mun, G. F. Wang, P. N. Ross, C. A. Lucas, N. M. Marković, Improved oxygen reduction activity on $\mathrm{Pt}_{3} \mathrm{Ni}$ (111) via increased surface site availability, Science 315 (2007) 493-497.

[6] M. K. Debe, Electrocatalyst approaches and challenges for automotive fuel cells, Nature 486 (2012) 43-51.

[7] S. J. Guo, S. Zhang, S. H. Sun, Tuning nanoparticle catalysis for the oxygen reduction reaction, Angew. Chem. Int. Ed.52 (2013) 8526-8544.

[8] Y. H. Bing, H. S. Liu, L. Zhang, D. Ghosh, J. J.Zhang, Nanostructured Pt-alloy electrocatalysts for PEM fuel cell oxygen reduction reaction, Chem. Soc. Rev. 39 (2010) 2184-2202.

[9] B. Lim, M. J. Jiang, P. H. C. Camargo, E. C. Cho, J. Tao, X. M. Lu, Y. M. Zhu, Y. N. Xia, Pd-Pt bimetallic nanodendrites with high activity for oxygen reduction, Science 324 (2009) 1302-1305. 


\section{ACCEPTED MANUSCRIPT}

[10] K. P. Gong, F. Du, Z. H. Xia, M. Durstock, L. M. Dai, Nitrogen-doped carbon nanotube arrays with high electrocatalytic activity for oxygen reduction, Science 323 (2009) 760-764.

[11] L. M. Dai, Y. H. Xue, L. T. Qu, H.-J. Choi, J. B. Baek, Metal-free catalysts for oxygen reduction reaction, Chem. Rev. 115 (2015) 4823-4892.

[12] Y. Zhao, L. J. Liang, S. Chen, X. Z. Wang, Y. W. Ma, Q. Wu, Y. F. Jiang, W. J. Qian, Z. Hu, Can boron and nitrogen co-doping improve oxygen reduction reaction activity of carbon nanotubes, J. Am. Chem. Soc. 135 (2013) 1201-1204.

[13]L. Lin, Q. Zhu, A.-W. Xu, Noble-metal-free Fe-N/C catalyst for highly efficient oxygen reduction reaction under both alkaline and acidic conditions, J. Am. Chem. Soc. $136(2014)$ 11027-11033.

[14] W. Zhang, Z. Y. Wu, H. L. Jiang, S. H. Yu, Nanowire-directed templating synthesis of metal-organic framework nanofibers and their derived porous doped carbon nanofibers for enhanced electrocatalysis, J. Am. Chem. Soc. 136 (2014) $14385-14388$.

[15] Y. J. Chen, S. F. Ji, Y. G. Wang, J. C. Dong, W. X. Chen, Z. Li, R. A. Shen, L. R. Zheng, Z. B. Zhuang, D. S. Wang, Y. D. Li, Isolated single iron atoms anchored on $\mathrm{N}$-Doped porous carbon as an efficient electrocatalyst for the oxygen reduction reaction, Angew. Chem. Int. Ed. 56 (2017) 6937-6941.

[16] S. Y. Gao, B. F. Fan, R. Feng, C. L. Ye, X. J. Wei, J. Liu, X. H. Bu, $\mathrm{N}$-doped-carbon-coated $\mathrm{Fe}_{3} \mathrm{O}_{4}$ from metal-organic framework as efficient electrocatalyst for ORR, Nano Energy 40 (2017) 462-470. 


\section{ACCEPTED MANUSCRIPT}

[17] Y. Y. Liang, Y. G. Li, H. L. Wang, J. G. Zhou, J. Wang, T. Regier, H. J. Dai, $\mathrm{Co}_{3} \mathrm{O}_{4}$ nanocrystals on graphene as a synergistic catalyst for oxygen reduction reaction, Nat. Mater.10 (2011) 780-786.

[18] Y. Y. Liang, H. L. Wang, J. G. Zhou, Y. G. Li, J. Wang, T. Regier, H. J. Dai,Covalent hybrid of spinel manganese-cobalt oxide and graphene as advanced oxygen reduction electrocatalysts, J. Am. Chem. Soc. 134 (2012) 3517-3523.

[19] G. Q. Zhang, B. Y. Xia, X. Wang, X. W. Lou, Strongly coupled $\mathrm{NiCo}_{2} \mathrm{O}_{4}-\mathrm{rGO}$ hybrid nanosheets as a methanol-tolerant electrocatalyst for the oxygen reduction reaction, Adv. Mater. 26 (2014) 2408-2412.

[20] Z. Y. Wu, X. X. Xu, B. C. Hu, H. W. Liang, Y. Lin, L.F. Chen, S.H. Yu, Iron carbide nanoparticles encapsulated in mesoporous Fe-N-doped carbon nanofibers for efficient electrocatalysis, Angew. Chem. Int. Ed.127 (2015) 8297-8301.

[21] J. Wang, H. H. Wu, D. F. Gao, S. Miao, G. X. Wang, X. H. Bao, High-density iron nanoparticles encapsulated within nitrogen-doped carbon nanoshell as efficient oxygen electrocatalyst for zinc-air battery, Nano Energy 13 (2015) 387-396.

[22] Y. L. Zhao, L. Xu, L. Q. Mai, C. H. Han, Q. Y. An, X. Xu, Y. Liu, Q. J. Zhang, Hierarchical mesoporous perovskite $\mathrm{La}_{0.5} \mathrm{Sr}_{0.5} \mathrm{CoO}_{2.91}$ nanowires with ultrahigh capacity for Li-air batteries, Proc. Nat. Acad. Sci., U. S. A. 109 (2012) 19569-19574. [23] J. J. Xu, D. Xu, Z. L. Wang, H. G. Wang, L. L. Zhang, X. B. Zhang, Synthesis of perovskite-based porous $\mathrm{La}_{0.75} \mathrm{Sr}_{0.25} \mathrm{MnO}_{3}$ nanotubes as a highly efficient electrocatalyst for rechargeable lithium-oxygen batteries, Angew. Chem. Int. Ed. 52 (2013) 3887-3890. 


\section{ACCEPTED MANUSCRIPT}

[24] M. Risch, K. A. Stoerzinger, S. Maruyama, W. T. Hong, I. Takeuchi, Y.

Shao-Horn, $\mathrm{La}_{0.8} \mathrm{Sr}_{0.2} \mathrm{MnO}_{3-\delta}$ decorated with $\mathrm{Ba}_{0.5} \mathrm{Sr}_{0.5} \mathrm{Co}_{0.8} \mathrm{Fe}_{0.2} \mathrm{O}_{3-\delta}$ : a bifunctional surface for oxygen electrocatalysis with enhanced stability and activity, J. Am. Chem. Soc. 136 (2014) 5229-5232.

[25] W. Zhou, J. Sunarso, Enhancing bi-functional electrocatalytic activity of perovskite by temperature shock: a case study of $\mathrm{LaNiO}_{3-\delta}$, J. Phys. Chem. Lett. 4 (2013) 2982-2988.

[26] Z. Chen, A. P. Yu, D. Higgins, H. Li, H. J. Wang, Z. W. Chen, Highly active and durable core-corona structured bifunctional catalyst for rechargeable metal-air battery application, Nano Lett. 12 (2012) 1946-1952.

[27] X. P. Han, F. Y. Cheng, T. R. Zhang, J. G. Yang, Y. X. Hu, J. Chen, Hydrogenated uniform Pt clusters supported on porous $\mathrm{CaMnO}_{3}$ as a bifunctional electrocatalyst for enhanced oxygen reduction and evolution, Adv. Mater. 26 (2014) 2047-2051

[28] X. P. Han, T. R. Zhang, J. Du, F. Y. Cheng, J. Chen, Porous calcium-manganese oxide microspheres for electrocatalytic oxygen reduction with high activity, Chem. Sci. 4 (2013) 368-376.

[29] E. Symianakis, D. Malko, E. Ahmad, A. S. Mamede, J. F. Paul, N. Harrison, A. Kucernak, Electrochemical characterization and quantified surface termination obtained by low energy ion scattering and X-ray photoelectron spectroscopy of orthorhombic and rhombohedral $\mathrm{LaMnO}_{3}$ powders, J. Phys. Chem. C 119 (2015) $12209-12217$. 
[30] J. Suntivich, H. A. Gasteiger, N. Yabuuchi, H. Nakanishi, J. B. Goodenough, Y. Shao-Horn, Design principles for oxygen-reduction activity on perovskite oxide catalysts for fuel cells and metal-air batteries, Nat. Chem. 3 (2011) 546-550.

[31] J. Suntivich, E. E. Perry, H. A. Gasteiger, Y. Shao-Horn, The influence of the cation on the oxygen reduction and evolution activities of oxide surfaces in alkaline electrolyte, Electrocatal. 4 (2013) 49-55.

[32] T. Poux, F. S. Napolskiy, T. Dintzer, G. Kéranguéven, S. Y. Istomin, G. A. Tsirlina, E. V. Antipov, E. R. Savinova, Dual role of carbon in the catalytic layers of perovskite/carbon composites for the electrocatalytic oxygen reduction reaction, Catal. Today 189 (2012) 83-92.

[33] G. Kéranguéven, S. Royer, E. Savinova, Synthesis of efficient Vulcan-LaMnO 3 perovskite nanocomposite for the oxygen reduction reaction, Electrochem. Commun. $50(2015) 28-31$.

[34] M. Kakihana, M. Arima, M. Yoshimura, N. Ikeda, Y. Sugitani, Synthesis of high surface area $\mathrm{LaMnO}_{3+\delta}$ by a polymerizable complex method, J. Alloy. Compd. 283 (1999) 102-105.

[35] T. Nitadori, T. Ichiki, M. Misono, Catalytic properties of perovskite-type mixed oxides $\left(\mathrm{ABO}_{3}\right)$ consisting of rare earth and $3 \mathrm{~d}$ transition metals. The roles of the A-and B-site ions, Bull. Chem. Soc. Jpn. 61 (1988) 621-626.

[36] A. Mahmood, M. F. Warsi, M. N. Ashiq, M. Sher, Improvements in electrical and dielectric properties of substituted multiferroic $\mathrm{LaMnO}_{3}$ based nanostructures synthesized by co-precipitation method, Mater. Res. Bull. 47 (2012) 4197-4202. 
[37] M. Rovezzi, C. Lapras, A. Manceau, P. Glatzel, R. Verbeni, High energy-resolution $\mathrm{x}$-ray spectroscopy at ultra-high dilution with spherically bent crystal analyzers of 0.5 m radius, Rev. Sci. Instrum. 88 (2017) 013108.

[38] G. T. Seidler, D. R. Mortensen, A. J. Remesnik, J. I. Pacold, N. A. Ball, A laboratory-based hard x-ray monochromator for high-resolution x-ray emission spectroscopy and x-ray absorption near edge structure measurements, Rev. Sci. Instrum. 85 (2014) 113906.

[39] D. R. Mortensen, G. T. Seidler, A. S. Ditter, P. Glatzel, Benchtop nonresonant X-ray emission spectroscopy: Coming soon to laboratories and XAS beamlines near you, J. Phys: Conf. Ser. 712 (2016) 012036.

[40] L. Kuai, J. Geng, E. J. Kan, C. Y. Chen, Y. D. Liu, Q. Wang, B. Y. Geng, A reliable aerosol-spray-assisted approach to produce and optimize amorphous metal oxide catalysts for electrochemical water splitting, Angew. Chem. Int. Ed. 126 (2014) 7677-7681.

[41] L. Kuai, J. X. Wang, T. Ming, C. H. Fang, Z. H. Sun, B. Y. Geng, J. F. Wang, Aerosol-spray diverse mesoporous metal oxides from metal nitrates, Sci. Rep. 5 (2015) 9923.

[42] T. Okumura, Y. Yamaguchi, H, Kobayashi, X-ray absorption near-edge structures of $\mathrm{LiMn}_{2} \mathrm{O}_{4}$ and $\mathrm{LiNi}_{0.5} \mathrm{Mn}_{1.5} \mathrm{O}_{4}$ spinel oxides for lithium-ion batteries: the first-principles calculation study, Phys. Chem. Chem. Phys. 18 (2016) 17827-17830. 


\section{ACCEPTED MANUSCRIPT}

[43] A. Y. Ramos, N. M. Souza-Neto, H. C. N. Tolentino, O. Bunau, Y. Joly, S.

Grenier, J.-P. Itié, A.-M. Flank, P. Lagarde, A. Caneiro, Bandwidth-driven nature of the pressure-induced metal state of $\mathrm{LaMnO}_{3}$, EPL, 96 (2011) 36002.

[44] J. G. Wang, Y. Yang, Z. H. Huang, F. Y. Kang, Rational synthesis of $\mathrm{MnO}_{2} /$ conducting polypyrrole@carbon nanofiber triaxial nano-cables for high-performance supercapacitors, J. Mater. Chem. 22 (2012) 16943-16949.

[45] E. Arendt, A. Maione, A. Klisinska, O. Sanz, M. Montes, S. Suarez, J. Blanco, P. Ruiz, Structuration of $\mathrm{LaMnO}_{3}$ perovskite catalysts on ceramic and metallic monoliths: Physico-chemical characterization and catalytic activity in methane combustion, Appl. Catal. A: General 339 (2008) 1-14.

[46] V. Celorrio, E. Dann, L. Calvillo, D. J. Morgan, S. R. Hall, D. J. Fermin, Oxygen reduction at carbon-supported lanthanides: The role of the B-site, ChemElectroChem 3 (2016) 283-291.

[47] A. J. Bard, L. R. Faulkner, Electrochemical Methods: Fundamentals and Applications, New York: Wiley, 1980.

[48] W. M. Wang, D. Zheng, C. Du, Z. Q. Zou, X. G. Zhang, B. J. Xia, H. Yang, D. L. Akins, Carbon-supported Pd-Co bimetallic nanoparticles as electrocatalysts for the oxygen reduction reaction, J. Power Sources 167 (2007) 243-249.

[49] K. A. Stoerzinger, M. Risch, B. H. Han, Y. Shao-Horn, Recent insights into manganese oxides in catalyzing oxygen reduction kinetics, ACS Catal. 5 (2015) 6021-6031. 


\section{ACCEPTED MANUSCRIPT}

[50] A. S. Ryabova, F. S. Napolskiy, T. Poux, S. Y. Istomin, A. Bonnefont, D. M. Antipin, A. Y. Baranchikov, E. E. Levin, A. M. Abakumov, G. Kéranguéven, E. V. Antipov, G. A. Tsirlina, E. R. Savinova, Rationalizing the influence of the Mn (IV)/Mn (III) red-ox transition on the electrocatalytic activity of manganese oxides in the oxygen reduction reaction, Electrochim. Acta 187 (2016) 161-172.

[51] J. Suntivich, H. A. Gasteriger, N. Yabuuchi, Y. Shao-Horn, Electrocatalytic measurement methodology of oxide catalysts using a thin-film rotating disk electrode, J. Electrochem. Soc. 157 (2010) B1263-B1268.

[52] C. L. Spiegel, Designing \&Building Fuel Cells, The McGraw-Hill Companies (2007).

[53] P. Patnaik, Handbook of Inorganic Chemicals, The McGraw-Hill Companies (2002).

[54] H. X. Zhang, J. Wang, Y. W. Zhang, W. -L. Xu, W. Xing, D. Xu, Y. F. Zhang, X. B. Zhang, ZIF-8 derived graphene-based nitrogen-doped porous carbon sheets as highly efficient and durable oxygen reduction electrocatalysts, Angew. Chem. Int. Ed. 53 (2014) 14235-14239.

[55] J. T. Mefford, W. G. Hardin, S. Dai, K. P. Johnston, K. J. Stevenson, Anion charge storage through oxygen intercalation in $\mathrm{LaMnO}_{3}$ perovskite pseudocapacitor electrodes, Nat. Mater. 13 (2014) 726-732.

[56] K. A. Stoerzinger, W. M. Lv, C. J. Li, Ariando, T. Venkatesan, Y. Shao-Horn, Highly active epitaxial $\mathrm{La}_{(1-\mathrm{x})} \mathrm{Sr}_{\mathrm{x}} \mathrm{MnO}_{3}$ surfaces for the oxygen reduction reaction: Role of charge transfer, J. Phys. Chem. Lett. 6 (2015) 1435-1440. 


\section{ACCEPTED MANUSCRIPT}
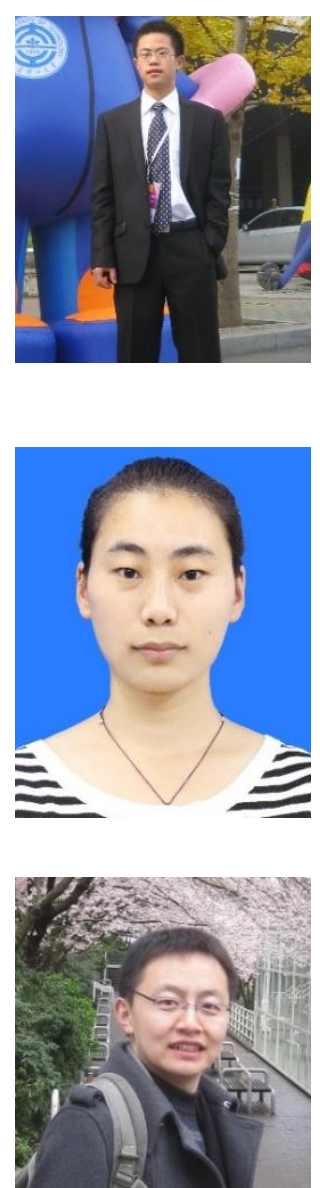

Dr. Long Kuai is currently a full-time staff in the School of Biological and Chemical Engineering, Anhui Polytechnic University since June, 2016. He received his both $\mathrm{BS}$ and $\mathrm{PhD}$ degree in Chemistry from Anhui Normal University in 2011 and 2016, respectively. His research interests focus on the design, preparation and the fundamental study of mesoporous catalysts for hydrogenation, electrical/chemical energy conversion, $\mathrm{CO}$ oxidation, and so forth.

Ms. Erjie Kan is currently a full-time staff in the School of Mechanical and Automotive Engineering, Anhui Polytechnic University since 2016. She received her Bachelor and Master of Engineering degree in Materials Science from Anhui Normal University in 2011 and 2015, respectively. Her research interests focus on the design and preparation of mesoporous supported catalysts for organic synthesis.

and Molecular Systems Research Unit, he is working on materials physics researches with special emphasis on developments of photocatalysts, first-principles predictions of novel low-dimensional materials, bio-inspired materials designs, and synchrotron radiation based characterizations.

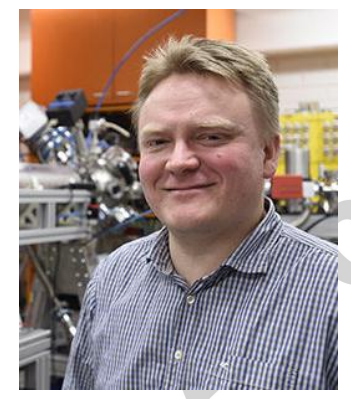

Prof. Marko Huttula completed his PhD degree in University of Oulu (Finland) in 2004 on the synchrotron based research of electronic structure of metal atoms. During the Academy of Finland Research Fellow post 2008-2012 and Post. Doc period in UPMC-Sorbonne Paris the research has focused to molecular and nanoscale materials and to the applications of spectroscopy and synchrotron radiation interdisciplinary and intersectorially. $\mathrm{He}$ is the Head of Nano and Molecular Systems Research Unit and coordinates the Finnish participation to MAX IV synchrotron radiation facility. He is developing tracks of doctoral training through heading multidisciplinary EU Horizon2020 doctoral programme "I4Future".

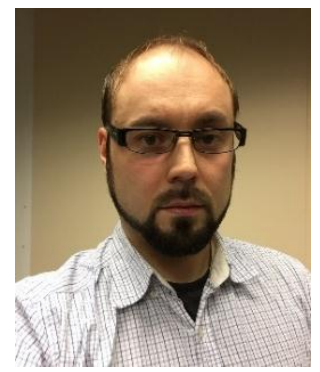

Mr. Sami Ollikkala is currently a M.Sc. student in Physics at the University of Helsinki under the supervision of Prof. Simo Huotari. His M.Sc. thesis field is in x-ray absorption spectroscopy. 


\section{ACCEPTED MANUSCRIPT}

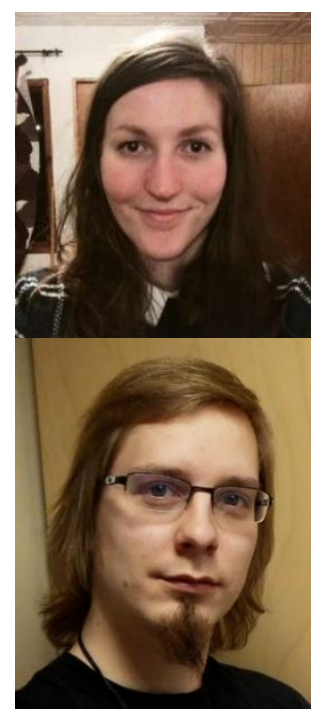

Ms. Taru Ahopelto is a Finnish M.Sc. student at the University at Aberdeen, and works together with Prof. Simo Huotari's group in x-ray spectroscopy applied to condensed matter physics.

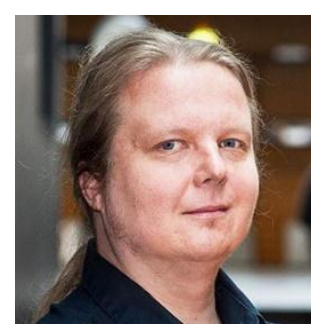

Prof. Simo Huotari received his Ph.D. degree from the University of Helsinki in 2003, after which he worked at the European Synchrotron Radiation Facility until 2010. He is currently a full professor in experimental materials physics at the University of Helsinki. His focus is developing and using advanced $\mathrm{x}$-ray methods for studies of materials.

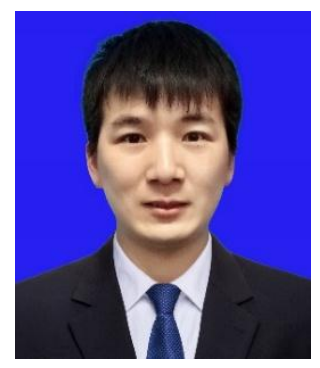

Mr. Wenhai Wang received his Bachelor of Science degree in Polymer Science and Engineering from Chizhou University in 2014 and Master of Engineering degree in Materials Science from Anhui Normal University in 2017. His research interests focus on the design and preparation of mesoporous materials for electrochemical oxygencatalysis toward the devices of fuel cells and metal-air batteries.

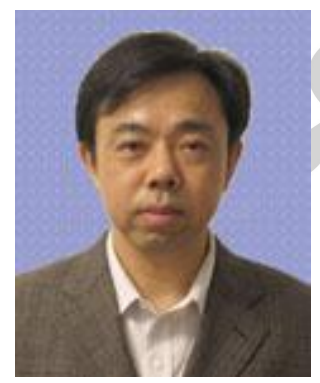

Dr. Baoyou Geng is a full professor and PhD supervisor in the College of Chemistry and Materials Science at Anhui Normal University. He received his $\mathrm{PhD}$ degree in Condensed Matter Physics from Chinese Academy of Sciences in 2004. Currently, his research interests focus on creating complex materials structures with nanoscale precision using chemical approaches, and studying their functionalities including catalysis, energy storage and conversion properties etc. He has published more than 100 research papers in the peer-reviewed journals. 


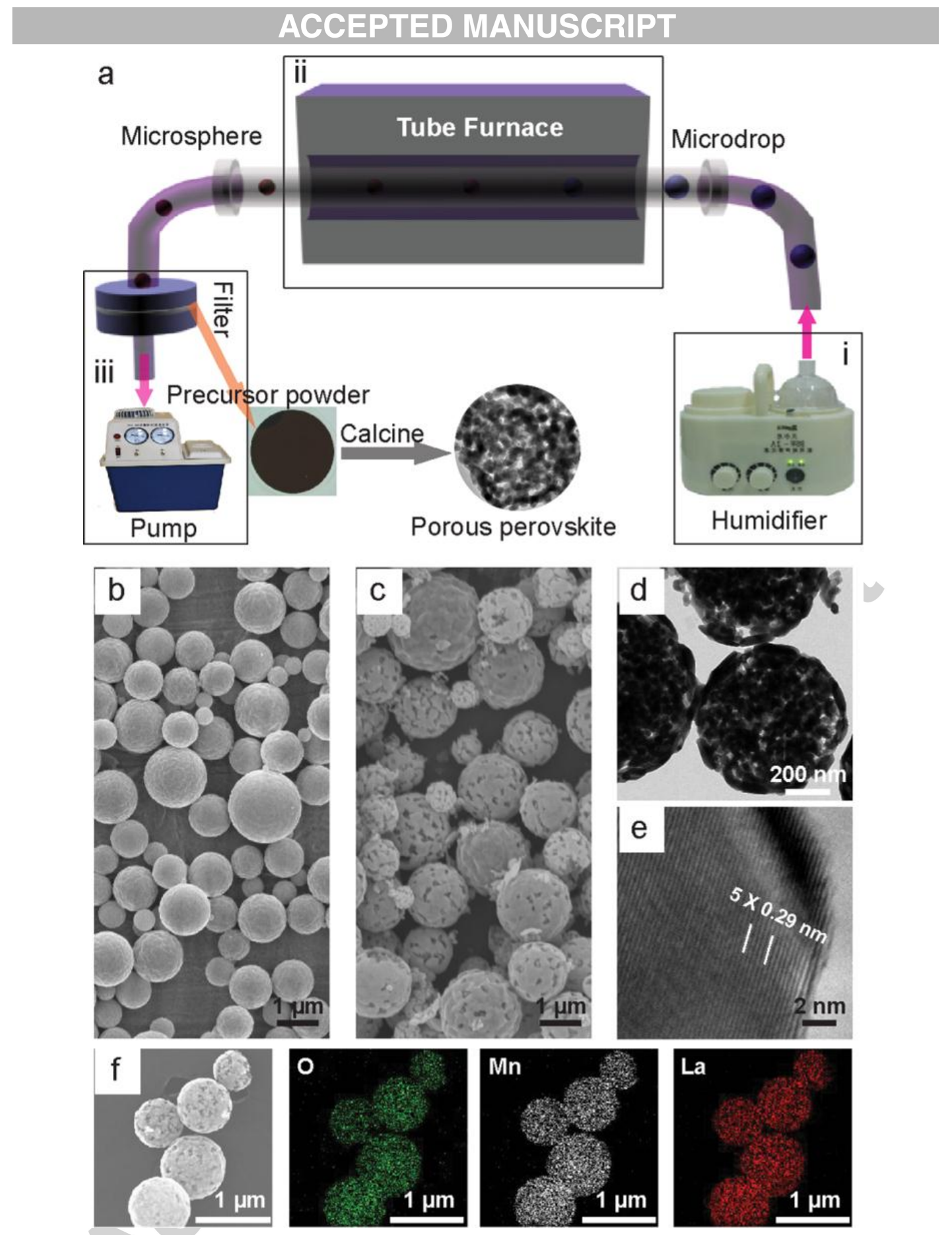

Fig. 1 The synthesis procedure (a) of mesoporous $\mathrm{LaMnO}_{3+8}$, SEM images of $\mathrm{LaMnO}_{3}$ precursor (b) and mesoporous $\mathrm{LaMnO}_{3+\delta}$ product (c), TEM (d), HRTEM (e) images, and EDX-mapping (f) of the mesoporous $\mathrm{LaMnO}_{3+\delta}$ microspheres. 


\section{ACCEPTED MANUSCRIPT}
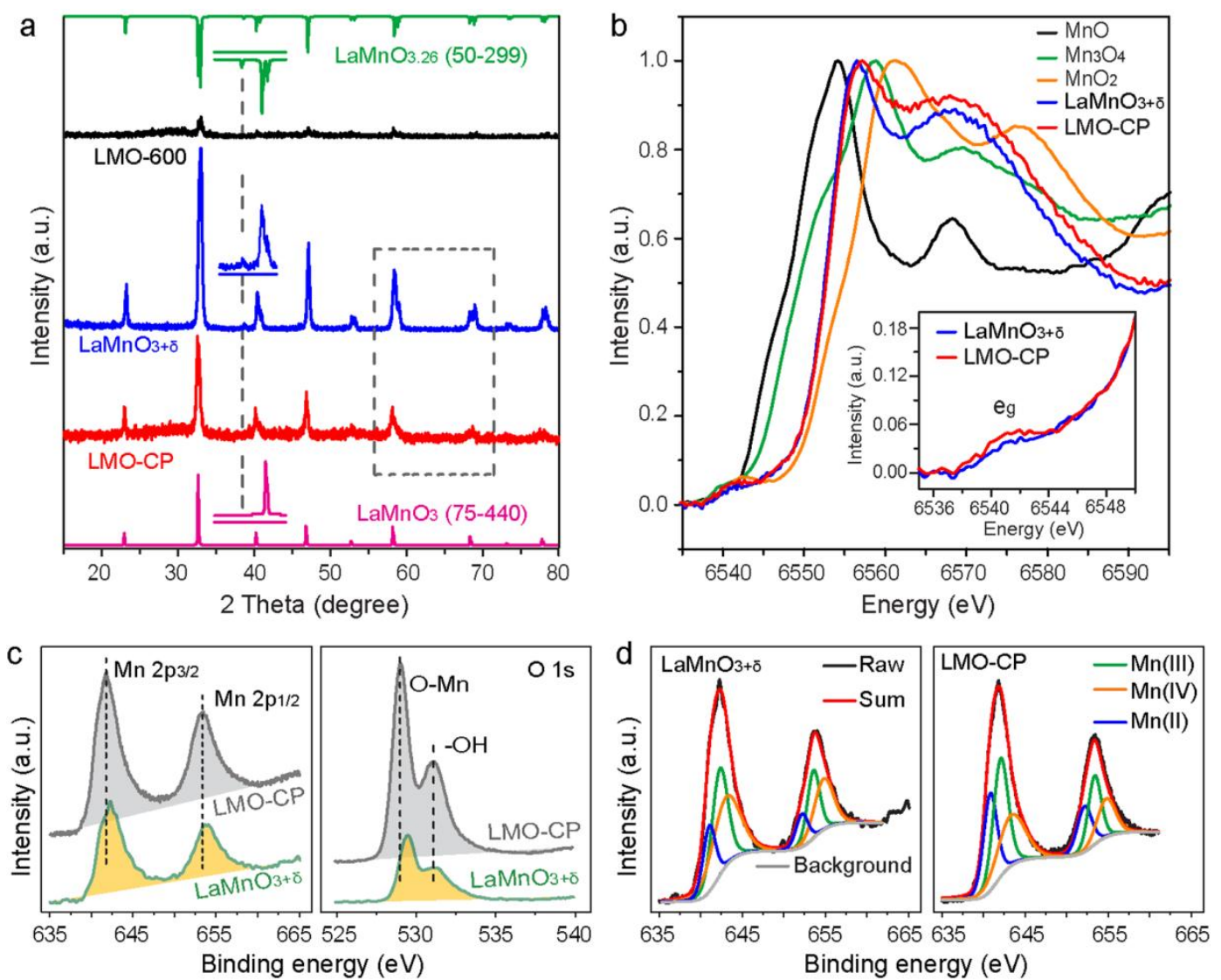

Fig. 2 (a) XRD patterns of $\mathrm{LMO}-600$ (black), mesoporous $\mathrm{LaMnO}_{3+\delta}$ (blue), LMO-CP (red) and the standard patterns of rhombohedral $\mathrm{LaMnO}_{3.26}$ (blue) and cubic $\mathrm{LaMnO}_{3}$ (pink); (b) Mn K-edge XANES spectra of various samples; (c) XPS Mn2p (left) and O1s (right) spectra of $\mathrm{LaMnO}_{3+\delta}$ (gray) and LMO-CP (green); (d) Fitted XPS Mn2p spectra of $\mathrm{LaMnO}_{3+\delta}$ (left) and LMO-CP (right). 


\section{ACCEPTED MANUSCRIPT}
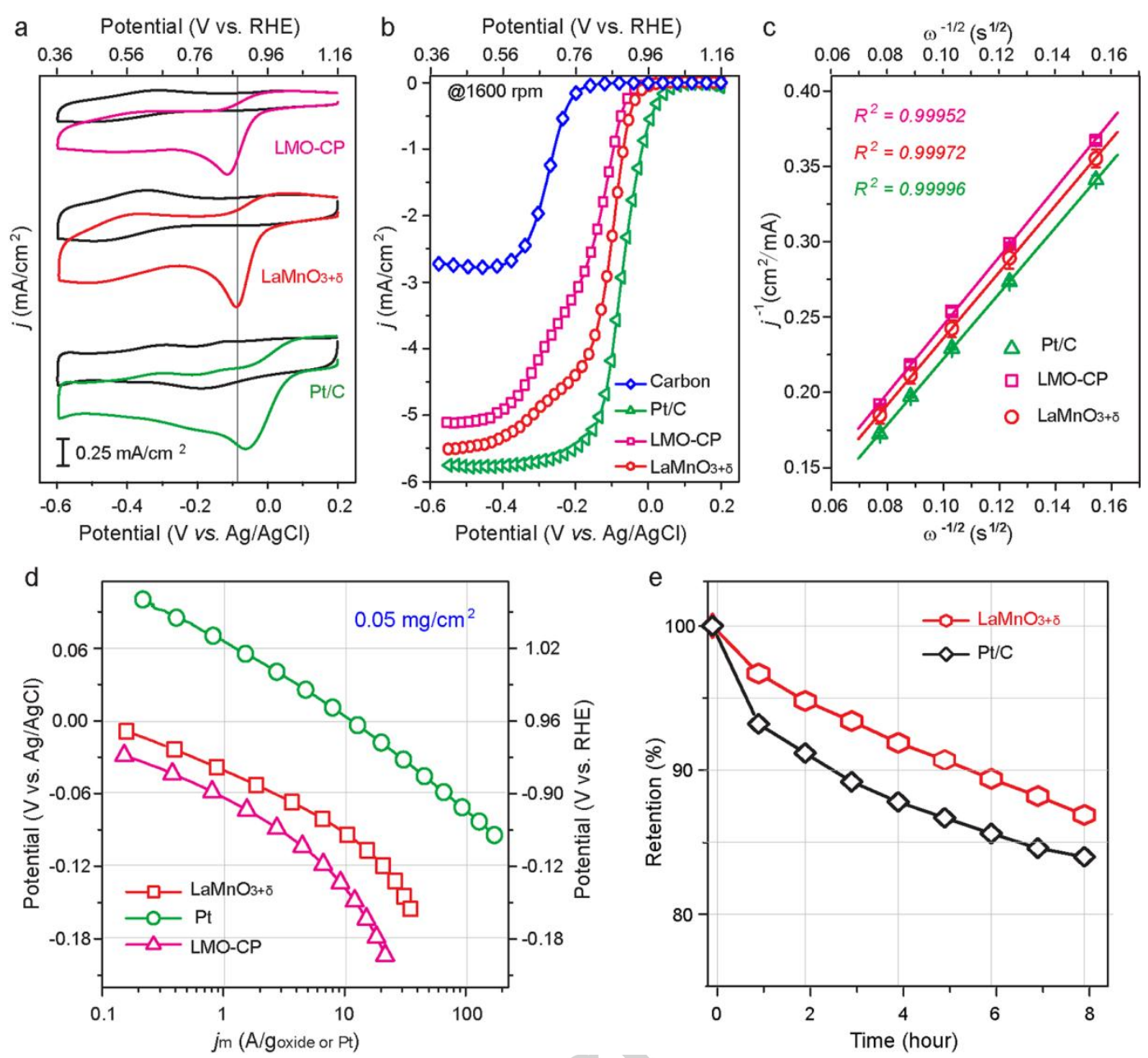

Fig. 3 CVs (a) and LSV curves (b), Koutecky-Levich analysis (c), and potential dependent mass activity plots (d) of mesoporous $\mathrm{LaMnO}_{3+\delta}$ (red), LMO-CP (pink) and commercial $\mathrm{Pt} / \mathrm{C}$ (green) catalysts, and retention plots after long-time electrocatalysis procedure (e) of $\mathrm{LaMnO}_{3+\delta}$ (red) and $\mathrm{Pt} / \mathrm{C}$ (black) catalysts. The error bars in Figure 3c represents the standard deviations of at least 3 independent tests. 


\section{ACCEPTED MANUSCRIPT}
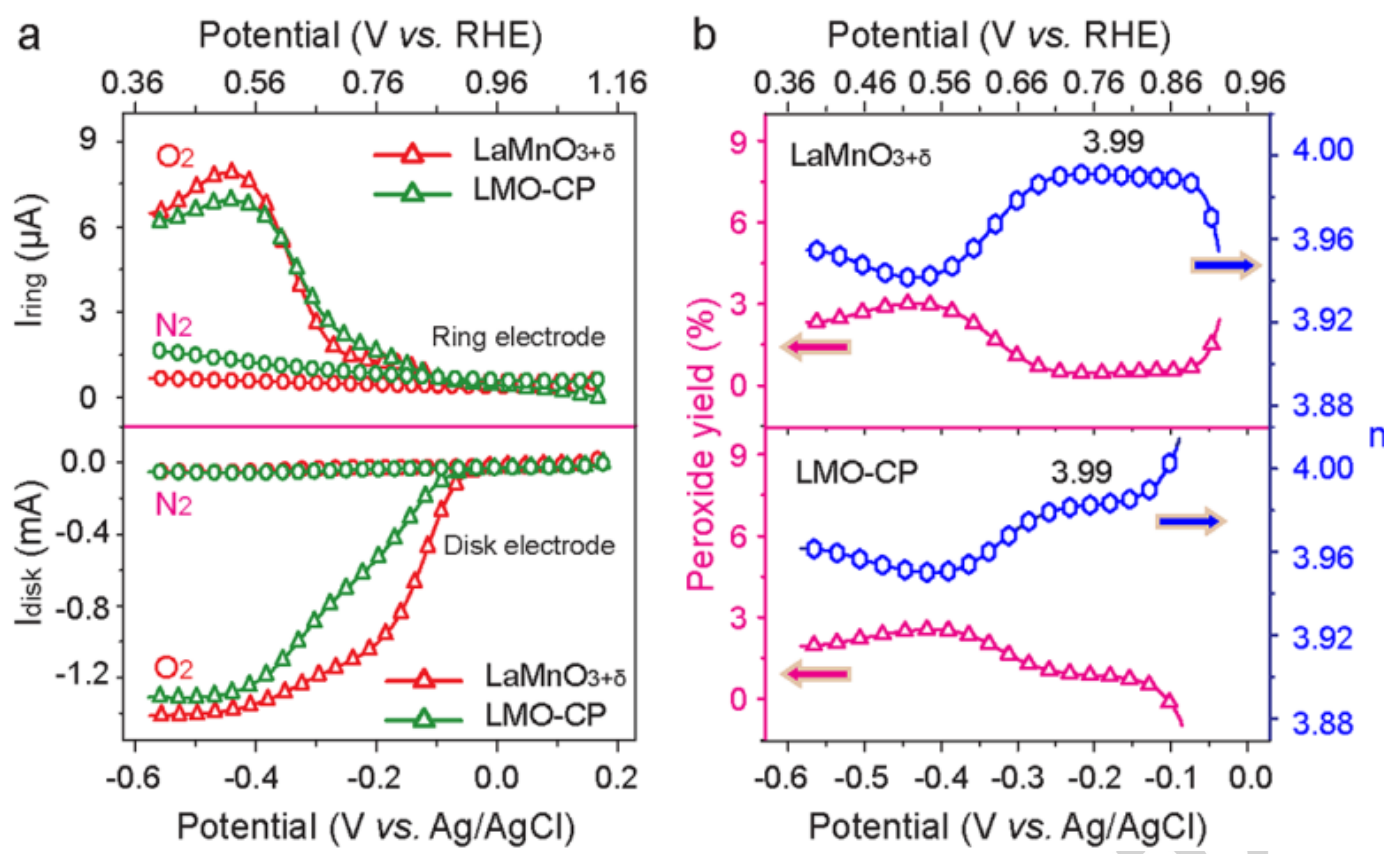

Fig. 4 RRDE tests (a) and potential-dependent peroxide yield (purple) and electron transfer numbers (n) (blue) of mesoporous $\mathrm{LaMnO}_{3+\delta}$ and LMO-CP catalyst at the rotation rate of $1600 \mathrm{rpm}$.
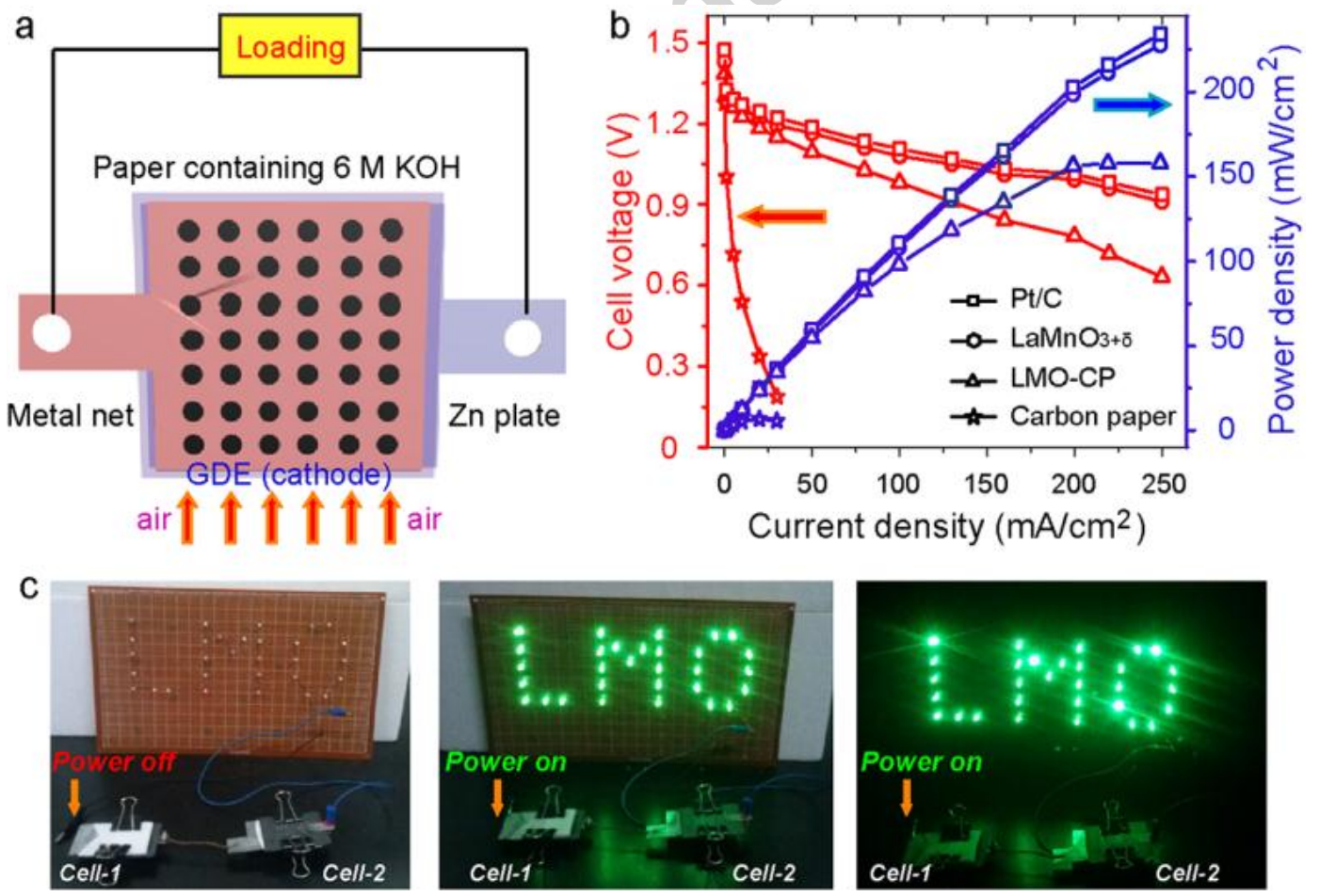

Fig. 5 (a) Scheme of our home-made Zn-air batteries. (b) I-V and I-P plots of Zn-air batteries with bare, mesoporous $\mathrm{LaMnO}_{3+\delta}$, LMO-CP and commercial Pt/C 


\section{ACCEPTED MANUSCRIPT}

catalysts-modified GDE. (c) Digital photos (Left: power-off under daylight; Middle: power-on under daylight; Right: power-on under dark) of "LMO" shaped light-emitting diodes powered by two tandem $\mathrm{Zn}$-air batteries with $\mathrm{LaMnO}_{3+\delta}$ as catalyst.

Table 1. A summary of ORR and $\mathrm{Zn}$-air batteries' performance with $\mathrm{LaMnO}_{3+\delta}$, LMO-CP and commercial Pt/C catalysts.

\begin{tabular}{|c|c|c|c|c|c|c|c|c|}
\hline \multirow{2}{*}{ Materials } & \multirow{2}{*}{$\begin{array}{l}\text { Loading } \\
\mathrm{mg} / \mathrm{cm}^{2}\end{array}$} & \multirow{2}{*}{$\begin{array}{l}E_{p} \\
V\end{array}$} & \multirow{2}{*}{$\begin{array}{c}j_{\mathrm{p}} \\
\mathrm{mA} / \mathrm{cm}^{2}\end{array}$} & \multirow{2}{*}{ 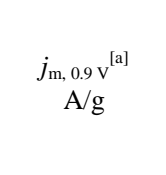 } & \multirow{2}{*}{$\mathrm{n}_{0.9 \mathrm{~V}}$} & \multicolumn{3}{|c|}{$\begin{array}{c}\text { Voltage of } \mathrm{Zn} \text {-air batteries } \\
\mathrm{V}\end{array}$} \\
\hline & & & & & & $\mathrm{V}_{\mathrm{OC}}$ & $\frac{\mathrm{V}}{1 \mathrm{~mA} / \mathrm{cm}^{2}}$ & $\frac{\mathrm{V}}{10 \mathrm{~mA} / \mathrm{cm}^{2}}$ \\
\hline $\mathrm{LaMnO}_{3+\delta}$ & 0.25 & 0.872 & 0.57 & $2.83 \pm 0.20$ & 3.99 & 1.430 & 1.322 & 1.255 \\
\hline LMO-CP & 0.25 & 0.845 & 0.75 & $0.90 \pm 0.10$ & 3.99 & 1.384 & 1.309 & 1.225 \\
\hline $\mathrm{Pt} / \mathrm{C}$ & 0.25 & 0.897 & 0.64 & $63.05 \pm 4.45^{[\mathrm{b}]}$ & 4 & 1.473 & 1.324 & 1.271 \\
\hline
\end{tabular}

[a] The mass activity was calculated with catalyst loading of $0.05 \mathrm{mg} \mathrm{cm}^{-2}$.

[b] The $j_{\mathrm{m}}$ was normalized by the loading of metallic $\mathrm{Pt}(10 \mu \mathrm{g})$.

\section{Highlights}

- A device-feasible mesoporous $\mathrm{LaMnO}_{3+\delta}$ catalysts with commercial $\mathrm{Pt} / \mathrm{C}$ comparable performance was developed by a spray-pyrolysis approach for ORR and $\mathrm{Zn}$-air batteries.

- It is confirmed that the surface $\mathrm{Mn}$ with a high $\mathrm{Mn}^{4+}$ proportion is positive to the ORR activity. 